\title{
Ethnicity Issues as a Political Mobilization Instrument of Cornelis MH in 2007 West Kalimantan Direct Elections
}

\author{
Khuswatun Hasanah \\ Department of Political Science, Univeritas Indonesia, Depok, Indonesia \\ Email: khuswatununj@gmail.com
}

\begin{abstract}
The New Order regime opened the opportunity for the community to participate in democratic activities. This is also felt by ethnic Dayaks who have experienced marginalization in the opportunity to take office in the region. Ethnic awareness driven by the desire of Dayak ethnic community due to termarginalisasi supported also by Law Number 32 Year 2004 on Regional Government. Dayak ethnicists are working hard to enter the government. One of them is through mass mobilization using ethnicity issue in Pilkada. In this research, the theory used is the theory of R. Paul Brass about ethnicity. The main argument is that marginalization will result in ethnic consciousness. Furthermore, ethnicity alone is not sufficient to explain the success of mobilization, thus requiring strong institutions to be more effective in the process of mobilizing with ethnicity as an instrument. The result of this research is true that in Dayak ethnic builds strong mobilization by mobilizing the established social organization as an amplifier of mobilization instrument in Election of West Kalimantan 2007.
\end{abstract}

Keywords- Democration, Ethnicity, Mobilization, Elections.

\section{INTRODUCTION}

The history of regional autonomy in Indonesia is an interesting issue to be observed and studied, because since the founding construct state format, the issues concerning local governance has been accommodated in Article 18 UUD 1945 along with an explanation. Although the state of RI adheres to the principle of a unitary state with a center of power is at the center but, because of the heterogeneity of the Indonesian nation better social conditions, economy, culture, and diversity of the level of public education, the decentralization or the distribution of power / authority of the central government needs to be channeled to regions berotonom.

The collapse of the New Order regime and the implementation of regional autonomy in the early days of reform provide a significant impact on the dynamics of local politics. Through the granting of autonomy, the principle of plurality in more democracy can be guaranteed, the effectiveness in local governance more can be realized, and the central government would not mind the burden of handling domestic affairs. The role of the Regional Representatives Council (DPRD) and the local leadership recruitment process has undergone a change and development of the post-New Order.

Regarding the plurality of events may be different if the areas that receive the autonomy overly enthusiastic, poor experience, or lack counseling and guidance from the central government. Autonomy in their dictionary is defined as ethnocentrism, tribalism, regionalism, or spirit-paced concerned tribes, regions and social groups "we" own. They become selfish and does not care about the other parts, the other areas, even with the top level of government. Post-enactment of regional autonomy in Indonesia, the ethnic-clad regional sentiment continued to show its shape. ${ }^{1}$ It can thus be seen in the presence of a decentralized system that followed also the regional authority to organize local elections (elections) directly is inseparable from the phenomenon of ethnicity in practice. Spirit of regionalism and ethnicity gave rise to the phenomenon of identity politics, where many ethnic and religious considerations in participating, especially in the realm of politics, either by the people as voters and elites who advanced in the recruitment of local leadership through elections.

\subsection{Problem}

Birth of Law Number 32 Year 2004 (UU 32/2004) on Regional Government the legal basis and foundation of regional autonomy is a fresh breeze to achieve democratization. In a political perspective, the law explicitly indicate a change in the management paradigm of politics and government, from the originally

\footnotetext{
${ }^{1}$ Bungaran Antonius Simanjuntak, Autonomy, ethnonationalism, and Future of Indonesia, (Jakarta: Yayasan Pustaka Torch 2010), pp. 155
} 
centralized into decentralized. ${ }^{2}$ Democratization is also influenced the dynamics of local politics in West Kalimantan after the New Order, especially for ethnic Dayak, where the New Order era, ethnic Dayak became ethnically restricted in position local governments do not like the Malays who had occupied several chairs positioned in government.

An important phenomenon that can be found in the local political dynamics of post-New Order that occurred in West Kalimantan is the strengthening of the local political elite's consolidation of power, especially after regional leaders are elected directly since 2005. However, the implications of the dynamics of local politics as it is the emergence of a factor ethnicity as an important factor in the control of local governance issues. The recruitment process leader in the region tends to be based on parameters that primordial, which facilitates the development of the spirit of regionalism and tribalism. ${ }^{3}$ Reforms and the direct election of governors live in the era of democracy and regional autonomy for ethnic Dayak opportunities to make choices on their own ethnic group as a leader in the region. It is characterized by the election of Cornelis Christiandy on direct elections in 2007 as the first direct elections held in West Kalimantan.

In the elections of West Kalimantan, which was held November 2007, there were four candidates that couples incumbent Usman Djafar and LH Kadir (Islamic Malay-Dayak Christians) promoted by 8 party Golkar, PPP, PKB, PAN, PKS, PDS, the Freedom Party, and PBR. Then the second pair namely Usman Sapta Odang and Ignatius Liong (Bugis-Padang-Islamic and Christian Dayak) that was carried forward Adil coalition Prosperous Kalbar consisting of PIB, Patriot Party, PBSB, Democrat, PKPB, PNI Marhaenisme, and the Regional Unity Party. Third, there is a pair Akil Mochtar and AR Mecer (Malay Islamic-Christian Dayak) of the People coalition Kalbar Union and supported by PPDK, PNBK, PKPI, PPDI, UN, Pelopo Party, PSI, and PPNUI. While the couple Cornelis MH-Christiandy Sanjaya (Christian Dayak-Chinese Christian) is only supported by one party that the PDIP. Even though, ${ }^{4}$

Of the total 13 districts / municipalities, Cornelis-Christiandy pair won $43 \%$ of the vote in eight districts namely Bengkayang, Singkawang, Hedgehog, Sanggau, Sekadau, Sintang, and Kapuas Hulu Melawi. While voting for candidates of ethnic Malays has a total

${ }^{2}$ Sri Astuti Buchari Resurrection Towards Ethnic Identity Politics, (Jakarta: Yayasan Pustaka Obor Indonesia, 2014), p. 3

${ }^{3}$ Jumadi in Sri Astuti Buchari, Ibid, p. 4

${ }^{4}$ Processed data from the Election Commission of West

Kalimantan, 2007

www.ijels.com of $57 \%$ of the vote but fragmented or divided to three candidates. Couple Usman Djafar and LH Kadir won in Sambas and Pontianak, while Usman Sapta-Ignatius Odang Liong win in the Ketapang village, and Akil Mochtar-AR Mecer reap only 9.66 percent of the vote in the remaining districts / cities with a voice that does not dominate. $^{5}$

The minimal number of the bearer partyChristiandy Cornelis couple on direct elections in 2007 did not become an obstacle in the victory Cornelis. In the process, it appears that the victory Cornelis tends to occur because of the Dayak ethnic revival that had suffered marginalization or ethnic class into two in its own country during the New Order. Community of West Kalimantan are ethnic Dayak majority tend to choose candidates coming from the same ethnic though the governor and deputy governor of the same religion with the majority of the population of West Kalimantan. The majority of the indigenous population is Muslim while West Kalimantan Governor Cornelis Catholic and Vice Governor Christiandy Protestant. ${ }^{6}$

Through discourse native son, Cornelis brought the issue of Dayak ethnic revival as one of the tools or political strength in mobilizing voters in direct elections of 2007. The issue of ethnic revival namely, that it is time Dayaks manju be number 1 in their homeland after suffering marginalization or marginality in Order New. During the campaign, Cornelis promising a form of affirmation to the Dayak ethnic community that supports it when he was elected governor. Thus, support Dayaks become so important and needs to be maximized by Cornelis-Christiandy partner so that it becomes an instrument or tool scooped victory in the sound in the first direct elections in West Kalimantan in 2007. This is what will be discussed further in this article.

\subsection{Research Questions}

Based on the problems described then withdrawn a research question of "How does the issue of ethnicity into a tool of political mobilization in the direct elections of West Kalimantan after the New Order?

\section{FRAMEWORK THEORY OF ETHNICITY PAUL R BRASS}

Paul R Brass instrumentalists looked at from the perspective of ethnicity. Brass theory indicates whether

\footnotetext{
${ }^{5}$ Processed data from the Election Commission of West Kalimantan in 2007 and the article by Andreas Harsono, Pontianak heat, heat Politics, accessed at https://www.pantau.or.id/?/=d/514, On Saturday, December 16th, 2017

${ }^{6}$ Nina Widyawati, Ethnicity and Religion as a Political Issue, Jakarta: Yayasan Pustaka Obor Indonesia, 2014), p. 24
} 
an ethnic group mobilized by elite who are not satisfied to then develop communal solidarity. Brass rationalize that this mobilization will be successful depends on the extent to which the process of development of the communal consciousness so as to create organizational resources necessary to build and support the political movements and the government's response to the demands of the group. ${ }^{7}$ Theories of ethnic politicization significantly stressed about the inequality in the distribution of available resources and opportunities among different ethnic groups included in political terms. Simply put, nationalism and ethnic solidarity emerged as a response to the exploitation of indigenous groups by foreign groups or from one social class to another social class. ${ }^{8}$ Their exploitation of the group to make a group or ethnic community tried to reach and maintain their group rights through political action and political mobilization so as to strengthen their ethnic group. It is as stated by Michael Hechter that the movement of ethnic group identity is a form of solidarity with the marginalized that emerged as a reaction to discrimination and inequality, as well as appearing as a political consciousness to counter the dominant group of the privileged economic and political. ${ }^{9}$

Brass observed that in making a claim to be important ethnic groups in the political system, it takes a political organization, a skilled political leadership, and a strong resource for support for the interests of the ethnic group. Effective political organization and political leadership as well as a resource base to defend the interests of ethnic groups are variables that affect the achievement of the interests of an ethnic group. Political organization is a tool for an ethnic group to achieve achievement as well as evidence of achievement. Brass arguments that the attitude of loyalty to the ethnic groups exploited by the elite or the elite of the central leadership and the non-dominant groups to mobilize to defend the interests of their ethnic or achieving greater. This support can be more profitable politically in the system, it is represented in the political system that has been there, and provide economic benefits to compete with other groups. Brass clearly stated in perspective that:

"Cultural forms, values, and practices of ethnic groups political Become resources for elites in

${ }^{7}$ Paul R. Brass, Ethnicity and Nationalism: Theory and Comparison, (New Delhi: Sage Publications, 1941), p. 41

8 ibid

${ }^{9}$ Michael Hechter, Internal Colonialism: The Celtic Fringe in British National Development, (Berkeley: University if California Press, 1975), p. 363

www.ijels.com competition for political power and economic advantage." 10

Furthermore, the most successful political organization, according to Brass is that has managed to establish the boundaries of their group to match the political objectives set by them. Thus, an ethnic group is defined not only by language, religion, or claim territory, but also defined as political organizations pursuing selfinterest. ${ }^{11}$ In other words, according to Brass ethnicity is seen as an instrument or a tool used by the elite in the group that manipulates symbols of ethnic identity as a political mobilization to achieve the political goals of the group. Nevertheless, a successful political mobilization by Brass is not based solely on the rich tradition and culture of ethnic groups but more important is the strength of traditional institutions. Cultural factors alone, simply can not explain the success of mobilization but must be coupled with strong institutions to be effective as an instrument of ethnic mobilization through. ${ }^{12}$

Paul Brass theory this would be related analysis tool of ethnic politics in answering this issue that is related to politics ethnicity as a means of achieving political interest in the elections so that Cornelis $\mathrm{MH}$ West Kalimantan can reap the dominant voice as a native son of the region in the post-New Order elections practices.

\section{RESULTS}

\section{Dayak Ethnic Awareness 3.1 Post-New Order}

Cornelis success in his election as governor of West Kalimantan in 2007 was a great success for the figures in knitting Dayak ethnic issues and religious, injustice and marginalization as the main political instrument in raising social and political consciousness of the Dayak community. The phenomenon of ethnic consciousness, identity politics and the demands of balancing political representation in West Kalimantan has a long history, it is more widely practiced by the Dayak community rather than the Malay community that has a more powerful political position in West Kalimantan, especially when the New Order regime. In the New Order era, the Malays since the beginning has been to get a good position in the government, evidenced by the Malays as a third group who dominate the government and bureaucracy in West Kalimantan after the military and Javanese ethnic group appointed by the central government during the New Order. Meanwhile, the condition of marginalization actually experienced by the Dayak ethnic society, where the political aspects, the government limits the activity of ethnic Dayak leaders to

${ }^{10}$ Paul R. Brass, op.cit., P. 15
${ }^{11}$ Paul R. Brass, op.cit., P. 43
${ }^{12}$ Paul R. Brass, op.cit., P 74 
occupy strategic positions in the government. Conditions of marginalization more experienced by the Dayak Ethnic namely the role of participation for ethnic Dayaks in the New Order era was not actively involve them in participating progress for ethnic, but rather the willingness to hand over the lands owned by them to the government to manage others. Meanwhile, the condition of marginalization actually experienced by the Dayak ethnic society, where the political aspects, the government limits the activity of ethnic Dayak leaders to occupy strategic positions in the government. Conditions of marginalization more experienced by the Dayak Ethnic namely the role of participation for ethnic Dayaks in the New Order era was not actively involve them in participating progress for ethnic, but rather the willingness to hand over the lands owned by them to the government to manage others. Meanwhile, the condition of marginalization actually experienced by the Dayak ethnic society, where the political aspects, the government limits the activity of ethnic Dayak leaders to occupy strategic positions in the government. Conditions of marginalization more experienced by the Dayak Ethnic namely the role of participation for ethnic Dayaks in the New Order era was not actively involve them in participating progress for ethnic, but rather the willingness to hand over the lands owned by them to the government to manage others.

When entering the reform, the implementation of decentralization finally opens opportunities and faucets of political participation in the Dayak ethnic group. Reforms in all sectors become the main lighter for the rebirth of a cultural identity in motion the existence of local cultural dynamics, namely to encourage the emergence of ethnic consciousness to present themselves in the local political arena. Strengthening ethnic identity rests on three dominant force that is religion, ethnicity, and culture, the more crystallized triggered by democratization and decentralization. ${ }^{13}$ Marginalization cause Dayak ethnic consciousness that is needed to end the ethnic struggles these conditions. When applied to direct elections, the Dayak ethnic society will tend to choose leaders who are ethnic Dayak because they thought that these leaders better understand the problems that occurred in the community so as to create the right solution. ${ }^{14}$

As evidence of the need for awareness of ethnic identity and ethnic struggles in the struggle for political opportunity equalization reform era, evidenced by the political movement Dayak elites that are agressive and

\footnotetext{
${ }^{13}$ Sri Astuti Buchari, op.cit., P. 58

${ }^{14}$ Jeany Hartriani, Ethnic Politics in the Reign of West Kalimantan Governor Cornelis in 2007 and 2013, Thesis Summary, (Depok: University of Indonesia, 2014), p. 11
}

assertive $^{15}$, Dayak elite capable of making Dayak Customary Council (MAD) as a forum to establish the identity and massive ethnic solidarity to the grassroots. The presence of indigenous organizations, religious and NGO also be evidence of the strengthening of Dayaks in political movements in West Kalimantan. Activists Dayak started to gather some social and religious organization such as the Institute Dayakologi, Movement Scholars Dayak, Association of Catholic Union of Intelligence Kristen Indonesia (PIKI), Credit Union, the priesthood, and the Council of Traditional Chinese Culture (MABT) be evidence of Dayak elite movement in order to increase awareness in the struggle to balance ethnic Dayak political opportunities especially in West Kalimantan.

When compared with the Dayak ethnic movement so intense pursuit of ethnic consciousness, ethnic Malays are even more tenuous in solidarity keetnisannya. The number of people of ethnic Malays in West Kalimantan it is fragmented in terms of political power and the strength of the weak NGOs. In particular, ethnic Dayak political maneuvering at the level of local politics in the reform era is more solid than the Malay ethnic group. This is because internal Malay ethnic groups there are different interests that later cause they can not unite on behalf of ethnicity in political maneuvering. Moreover, people Ethnic Malays also have a fairly since the beginning (New Order) to get a good position in the government. ${ }^{16}$

\section{III.2 Issue Dayak Ethnic Revival as a Tool of Political Mobilization}

Ethnic aspect should not be overlooked role in local politics in Indonesia. This is evident in the legislative elections and the election process. Voter mobilization can be done by raising issues relating to ethnicity, whether ethnic, religious and designations natives or newcomers. Candidate ethnic background a little more influence voter choice. This is especially true in areas that have ethnic balance where there are two or more dominant tribe in the area, one of the first examples in West Kalimantan. A support is used to exploit the political communication with the main message, sons of the soil and other ethnicities. Coupled with the religious affiliation disparity.

The emergence of ethnic politics initiated by the growing awareness that identifies them into a class or

\footnotetext{
${ }^{15}$ Jumadi and Mohd. Rizal Yaakop, Ethnic Representation in Political Leadership Post New Order, Journal of Democracy and Autonomy, Vol. 11, No. 2, December 2013, 71-143, p. 86

16 Jamie Seth Davidson, Violence and Politics in West Kalimantan, Indonesia, Dissertation, (Seattle: Universty of Washington, 2002), hlm.346
} 
ethnic group. This then raises awareness clustering and national solidarity. Identification of ethnic identity as commonly done in a multiethnic society has consistently been directed at the situation and the context in which a person resides. In the political context in the ethnically mixed area, especially during elections, the identification of ethnicity become necessity in behavior and political communication in both the activity and the role of political and social life in general, particularly in order to attract the sympathy of the electorate, the increasing popularity and political objectives other, called as situational ethnicity. ${ }^{17}$

In explaining how the issue of the resurrection Dayak used as an instrument or a tool in political mobilization by Cornelis to achieve their political goals which won the direct governor elections in the reform era can be seen with how the campaign promises made by Cornelis in attracting the masses and strengthen the pockets of supporters. In his campaign, Cornelis promised to provide maximum protection to the Dayak people who have been marginalized and sidelined. In addition, Cornelis also promised to undertake the distribution of development up to the inland and simplify the permission to build a church. Bureaucracy associated conditions previously dominated by ethnic Malays, ${ }^{18}$ Likewise Cornelis campaigners who claim that "Now is the time for the Dayak appeared as number one. For number two for sure. And if not now, then when. Today is the most favorable conditions ". Plus, the campaign Cornelis equipped with political jargon "United We Win" as a symbol of political struggle has become a magnet powerful political construct ethnic consciousness in politics in the area as well as make Cornelis optimistic will win direct elections in 2007 to unify the voices of ethnic Dayak and Christian Chinese ${ }^{19}$

The issue of revival of ethnicity in fact managed to become a strong factor affecting the results of the elections in West Kalimantan governor in 2007. This is evidenced by the following several interviews to voters about ethnicity as a primary consideration in choosing a governor candidate in the elections of 2007.

${ }^{17}$ Fredrik Barth, Mulyana in M. Nawawi, Haslinda B. Anriani, and Ilyas, Dynamics of Ethnicity and Political Conflict in the General Election, the Journal of the Society, Culture and Politics, Vol. 25, No. 3, 2012, 223-232, p. 226

${ }^{18}$ Rays of Hope, Incumbent Politics Religion Cause tumbles in Pilgub ordinance, Nov. 27, 2007, in the LSI Monthly Review Issue 09, January 2008, p. 4

${ }^{19}$ Jumadi and Mohd. Rizal Yaakop, op.cit., P. 84 www.ijels.com
"We Malays would vote for candidates of the Malays." - Aminuddin (34), coastal residents in Kubu Raya. ${ }^{20}$

"The idea is very simple citizens, leaders who come from a tribe believed to be fighting for the interests of citizens because of feelings of kinship and language." - Imran Manuk, Voters Dayak candidates for governor, the Village Head Tell Tembawang, Sanggau. ${ }^{21}$

"Most people use their right to vote because of the closeness of race, class, or religion with the candidates. "- Halian (30), a resident of Kampung Throughout, Sambang River Village, District Sekadau Hulu, Sekadau. ${ }^{22}$

It is most significant as evidence of success Cornelis public voice raked through the issue of ethnicity is a victory Cornelis revival in the district / city that is dominated by ethnic Dayak. Districts / cities that the Melawi, Kapuas Hulu, Sekadau, Bengkayang, Sintang, Sanggau, Porcupine, and Singkawang unanimously reached $43.67 \%$ or 930679 voters. The emergence of identity politics as an issue of ethnicity has managed to consolidate the Dayaks emotionally to win the Dayak leaders in the political contest. It is also a result of their efforts towards community mobilization by Cornelis Dayaks to achieve their political goals through the issue of ethnicity Dayak ethnic revival in the strategic position of the government.

Table.3.1: Distribution Map Ethnicity Census of 2000 and the results of West Kalimantan gubernatorial election

\begin{tabular}{|c|l|l|c|l|}
\hline \multicolumn{1}{|c|}{} & \multicolumn{1}{|c|}{ First } & $\begin{array}{c}\text { Secon } \\
\text { d } \\
\text { No } \\
\text { Larges } \\
\text { t } \\
\text { Cistrict / } \\
\text { Cargest } \\
\text { Ethnic } \\
\text { Group } \\
\text { Ethnic } \\
\text { Group }\end{array}$ & $\begin{array}{c}\text { Paslon victory } \\
\text { in West } \\
\text { Kalimantan } \\
\text { Governor } \\
\text { Election 2007 }\end{array}$ \\
\hline 1 & Melawi & Malay & dayak & $\begin{array}{l}\text { Cornelis - } \\
\text { Christiandy }\end{array}$ \\
\hline 2 & $\begin{array}{c}\text { Kapuas } \\
\text { Hulu }\end{array}$ & Malay & dayak & $\begin{array}{l}\text { Cornelis - } \\
\text { Christiandy }\end{array}$ \\
\hline 4 & Stuffed & dayak & Malay & $\begin{array}{l}\text { Cornelis - } \\
\text { Christiandy }\end{array}$ \\
\hline
\end{tabular}

${ }^{20} \mathrm{C}$ Rev Haryo PS and A Handoko, Election Identity Politics In the tug, an online newspaper article on pages http://megapolitan.kompas.com/read/2012/06/01/01 582764/pilkada.pada.tarikan.politik.identitas,

Accessed Saturday, December 16, 2017

21 ibid

22 ibid 


\begin{tabular}{|c|c|c|c|c|}
\hline 5 & Sintang & dayak & Malay & $\begin{array}{l}\text { Cornelis - } \\
\text { Christiandy }\end{array}$ \\
\hline 6 & Sanggau & dayak & Malay & $\begin{array}{l}\text { Cornelis - } \\
\text { Christiandy }\end{array}$ \\
\hline 7 & $\begin{array}{l}\text { Hedgeho } \\
\mathrm{g}\end{array}$ & dayak & Malay & $\begin{array}{l}\text { Cornelis - } \\
\text { Christiandy }\end{array}$ \\
\hline 8 & $\begin{array}{l}\text { Singkaw } \\
\text { ang }\end{array}$ & Chinese & Java & $\begin{array}{l}\text { Cornelis - } \\
\text { Christiandy }\end{array}$ \\
\hline 9 & $\begin{array}{l}\text { Pontiana } \\
\text { k (City) }\end{array}$ & Malay & $\begin{array}{l}\text { Chines } \\
\mathrm{e}\end{array}$ & $\begin{array}{l}\text { Usman - LH } \\
\text { Kadir }\end{array}$ \\
\hline 10 & $\begin{array}{l}\text { Pontiana } \\
\mathrm{k}\end{array}$ & Malay & $\begin{array}{l}\text { Madur } \\
\text { a }\end{array}$ & $\begin{array}{l}\text { Usman - LH } \\
\text { Kadir }\end{array}$ \\
\hline 11 & Sambas & Malay & $\begin{array}{l}\text { Chines } \\
\mathrm{e}\end{array}$ & $\begin{array}{l}\text { Usman - LH } \\
\text { Kadir }\end{array}$ \\
\hline 12 & $\begin{array}{l}\text { Kubu } \\
\text { Raya }\end{array}$ & Malay & Java & Akil - Mecer \\
\hline 13 & $\begin{array}{l}\text { North } \\
\text { Kayong }\end{array}$ & dayak & Malay & Akil - Mecer \\
\hline 14 & $\begin{array}{l}\text { Ketapan } \\
\mathrm{g}\end{array}$ & Malay & dayak & USO - Ignatius \\
\hline
\end{tabular}

Source: Source ethnic distribution of the BPS 2000 and win Paslon processed by author

Meanwhile, the voice for ethnic Malays are divided or fragmented to three other candidates promoted by many parties, unlike the case with CornelisChristiandy. The weakness of the Malay ethnic solidarity is suppose to be one factor of deterioration and failure of the Malay elite to compete with the elite Dayak. All three candidates who come from ethnic Malays reach up to $57 \%$ total votes only to be divided to three candidates. In addition, the support of NGOs and the role of indigenous organizations of ethnic Malays are not as solid as that carried out by the Dayaks. The things that made so successful Cornelis pitch as the winner of the election the governor of West Kalimantan in 2007 and brought the issue of ethnicity as an instrument of public sympathy in pursuit of political aims.

\section{DISCUSSION}

Study of issues related to ethnic revival which became an instrument of political mobilization in elections in West Kalimantan in 2007 is said to be relevant to the theory put forward Paul R. Brass that one ethnic group is mobilized by the elites who are not satisfied to then develop communal solidarity. Brass rationalize that this mobilization will be successful depends on the extent to which the process of development of the communal consciousness so as to create organizational resources necessary to build and support the political movements and the government's response to the demands of the group. ${ }^{23}$ It thus appeared to phenomena that occur in West Kalimantan that when the regime falls and faucets political participation is wide open during the reform era, in which also participated in the birth of Law Number 32 Year 2004 on Regional Government opened the opportunity for Dayaks to appear as the son area in direct elections were first held in 2007 after previously marginalized in the seat of government. Communal consciousness awakened in the Dayak ethnic communities to struggle out of the marginalization experienced during the New Order. Until then, this awareness becomes a powerful resource to participate in local politics in West Kalimantan.

Cornelis appear as a native son who brought the issue of ethnic revival and campaign promises to the promotion of Dayaks, especially in the balance position of the Dayak ethnic Malays in government strategic position. This becomes a powerful resource to gain support for the interests of the ethnic groups, primarily ethnic Dayak Cornelis in fighting at the same time fight for him in the election victory of 2007. Eight West Kalimantan district / city that won the elections Cornelis in 2007, also at the same time confirm the argument that the attitude of loyalty group Brass on ethnic exploited by the elite or the elite of the central leadership and the nondominant groups to mobilize to defend the interests of their ethnic or achieving greater. ${ }^{24}$

Nevertheless, further Brass said that a successful political mobilization by Brass is not based solely on the rich tradition and culture of ethnic groups but more important is the strength of traditional institutions. Therefore, the cultural factors alone, simply can not explain the success of mobilization but must be coupled with strong institutions to be effective as an instrument of ethnic mobilization through. ${ }^{25}$ This is confirmed by the phenomenon of the forces of social organization that consolidated well in giving political support to Cornelis, such as the Institute Dayakologi, Movement Scholars Dayak, Association of Catholic Union of Intelligence Kristen Indonesia (PIKI), Credit Union, the priesthood, and the Assembly of Indigenous Chinese culture (MABT). Solidity organization is exactly what is not owned by ethnic Malays, who since the beginning (New Order) has had a safe position in the government so that the movement was not as agressive and se-assertive elite Dayak, the actual impact on the deterioration and failure of the Malay elite against elite Dayak elections. Malays fragmented voice to the three candidates who promote themselves as a candidate for governor.

\footnotetext{
${ }^{23}$ Paul R. Brass, op.cit., P. 41

${ }^{24}$ Paul R. Brass, op.cit., P. 15

${ }^{25}$ Paul R. Brass, op.cit., P. 74
} 
In other words, the authors said Paul R. Brass theory is confirmed by both the phenomenon of election of the Governor of West Kalimantan in 2007 through a proof of the success of Cornelis mobilizing Dayaks through the issue of ethnic revival in winning votes in 8 districts / cities with majority ethnic Dayak in it on the fight politics in the first direct elections were held in West Kalimantan.

\section{CONCLUSION}

The collapse of the New Order regime and the birth of the era of reform to tap into such great political participation for ethnic Dayak during the New Order marginalized, marginalized in government posts and become second-class citizens in their own areas. Ethnic consciousness arise in addition driven by their desire to end the Dayak ethnic community marginalissi condition is also supported by the era of democratization and decentralization, as the implications of Law No. 32 of 2004 on Regional Government at that time in West Kalimantan.

Marginalization or marginalization of a group, according to Paul R. Brass will give birth to ethnic consciousness. West Kalimantan ethnic consciousness in post-New Order is marked by the political movement Dayak elites were agressive and assertive. Dayak Customary Council making to strengthen the Dayak ethnic solidarity to the grassroots and to build solidarity with stir ethnic social organizations such as the Institute Dayakologi and Intellectuals Movement to strengthen ethnic Dayak so that it can be a strong mass base as a source of political power. It is relevant to the theory put forward by Paul R. Brass that cultural factors only in terms of ethnicity was not enough to explain the success of the mobilization,

In addition to using the issue of revival of ethnic Dayak through his campaign promises to strengthen the existence of ethnic Dayaks in West Kalimantan when Cornelis was elected governor, in this case, Cornelis also succeeded in effecting ethnic mobilization to achieve their political goals to win the elections in West Kalimantan in 2007, reinforced by the support solid of social organization Institut Dayakologi, Dayak Intellectuals movement, Association of Catholic Union of Christian Indonesian Intelligence (PIKI), Credit Union, the priesthood, and the Indigenous Council of Chinese Culture (MABT).

\section{ACKNOWLEDGEMENT}

The author gratefully acknowledges to the Indonesia Endowment for Education for the funding through LPDP Scholarship. Any remaining errors are the author responsibility.

\section{Books}

\section{REFERENCES}

[1] Brass, Paul R. (1941). Ethnicity and Nationalism: Theory and Comparison. New Delhi: Sage Publication

[2] Buchari, Sri Astuti. 2014. Kebangkitan Etnis Menuju Politik Identitas. Jakarta: Yayasan Pustaka Obor Indonesia

[3] Djohan, Djohermansyah. (2007). Desentralisasi dan Otonomi Daerah: Desentralisasi, Demokratisasi, dan Akuntabilitas Pemerintah Daerah. Jakarta: LIPI Press

[4] Hechter, Michael. (1975). Internal Colonialism: The Celtic Fringe in British National Development. Berkeley: University if California Press

[5] Simanjuntak, Bungaran Antonius. (2010). Otonomi Daerah, Etnonasionalisme, dan Masa Depan Indonesia. Jakarta: Yayasan Pustaka Obor

[6] Widyawati, Nina. (2014). Etnisitas dan Agama sebagai Isu Politik. Jakarta: Yayasan Pustaka Obor Indonesia

\section{Journal and Dissertations}

[7] Davidson, Jamie Seth. (2002). Violence and Politics in West Kalimantan, Indonesia. Disertasi. Seattle: Universty of Washington

[8] Hartriani, Jeany. (2014). Politik Etnis pada Masa Pemerintahan Gubernur Cornelis di Kalimantan Barat Tahun 2007 hingga 2013. Ringkasan Skripsi. Depok: Universitas Indonesia

[9] Jumadi dan Yaakop, Mohd. Rizal. (2013). Keterwakilan Etnis dalam Kepemimpinan Politik Pasca Orde Baru, dalam Jurnal Demokrasi \& Otonomi Daerah, Vol. 11, No. 2, p. 71-143

[10]Nawawi, M, Anriani, Haslinda B, dkk. (2012). Dinamika Etnisitas dan Konflik Politik pada Pemilukada, dalam Jurnal Masyarakat, Kebudayaan dan Politik, Vol. 25, No. 3, p. 223-232

[11]Sinar Harapan. (2007). Politik Agama Penyebab Incumbent Tumbang di Pilgub Kalbar, edisi 27 November 2007

\section{Articles}

[12]C Wahyu Haryo PS dan A Handoko, Pilkada Pada Tarikan Politik Identitas, artikel koran online pada laman diakses di http://megapolitan.kompas.com/read/2012/06/01/01 582764/pilkada.pada.tarikan.politik.identitas, pada Sabtu, 16 Desember 2017

[13] Andreas Harsono, Panasnya Pontianak, Panasnya Politik, diakses di https://www.pantau.or.id/?/=d/514, pada Sabtu, 16 Desember 2017 